\title{
LUT
}

University

\section{Public Sector Communication and Citizen Expectations and Satisfaction}

Luoma-aho Vilma, Olkkonen Laura, Canel María-José

This is a Author's accepted manuscript (AAM) version of a publication

published by John Wiley \& Sons

in The Handbook of Public Sector Communication

DOI: $10.1002 / 9781119263203 . c h 20$

Copyright of the original publication: (c) 2020 John Wiley \& Sons, Inc.

Please cite the publication as follows:

Luoma-aho, V., Olkkonen, L. and Canel, M.-J. (2020). Public Sector Communication and Citizen Expectations and Satisfaction. In The Handbook of Public Sector Communication (eds V. Luomaaho and M.-J. Canel). doi:10.1002/9781119263203.ch20

This is the peer reviewed version of the article, which has been published in final form at https:// doi.org/10.1002/9781119263203.ch20. This article may be used for non-commercial purposes in accordance with Wiley Terms and Conditions for Use of Self-Archived Versions.

This is a parallel published version of an original publication. This version can differ from the original published article. 


\subsection{Public Sector Communication and Citizen Expectations and Satisfaction}

Vilma Luoma-aho*, Laura Olkkonen** and Maria-José Canel**

*University of Jyvaskyla, Finland

**Lappeenranta University of Technology, Finland

*** University of Complutense, Madrid, Spain, 


\begin{abstract}
When society and communication technologies change, citizen expectations follow suit. Expectations about the nature of communication with public sector organizations are changing from one-way information provision toward ongoing interaction and engagement, yet most public sector organizations have not been able to keep up with these new demands. To meet emerging citizen needs, public sector organizations must better understand the logic through which citizen expectations are formed, as well as the different types of expectations citizens may have. By monitoring and analyzing expectations, public sector communication can identify not only gaps between expectations and performance but also the cause of those gaps. Priming communication can help to set expectations at a realistic level, whereas unethical expectation management efforts can hurt organizational reputation and legitimacy.
\end{abstract}

\title{
INTRODUCTION
}

Citizen expectations change as society changes. As technology enables increased interaction and politics emphasize citizen activity, the myth of the passive citizen is giving way to citizens who ideally are "an active part of a common solution to social problems, bringing experiential expertise and local knowledge" (Durose, Justice, \& Skelcher, 2015, 139). Though not all citizens are active, they all have expectations and experiences that frame their interactions, attitudes, and behavior directed at public sector organizations (Morgeson, 2012). In fact, citizen experiences are formed when events are assessed against citizens' expectations, a process that gives the tacit, subconscious cues that we call "expectations" a central role in shaping the way in which individual citizens perceive public organizations' actions and communication (Castelo et al., 
2015; Dolan, Hallsworth, Halpern, King, \& Vlaev, 2010). Expectations also contribute to citizens' perceptions about public service quality, and thus expectations that are too high may actually backfire as citizens experience lower levels of satisfaction (Font \& Navarro, 2013; Poister \& Thomas, 2011a) or a loss of trust, while the organization experiences a loss of reputational capital (Luoma-aho, 2007).

Currently, traditional forms of mediatization and bureaucratic organization (Fredriksson, Schillemans, \& Pallas, 2015) are coming up against an emerging social media logic (Van Dijck \& Poell, 2013) that shapes not only how individuals expect organizations to respond and communicate, but also what is desirable. There is an urgent call for public sector organizations to move from "an architecture of speaking" toward "an architecture of listening" (Macnamara, 2015, 6), which makes transparency increasingly important for public sector communication. This further emphasizes the importance of citizen expectations and citizen satisfaction, as they set the future tone for all public sector performance and planning (Canel \& Luoma-aho, 2017).

The preservation of an organization's legitimacy depends on that organization's ability to identify, comprehend, and respond to the demands of its diverse stakeholder groups (Gardberg and Fombrun, 2006). Both what is expected of the organization and what the organization is willing to deliver need to be constantly negotiated between organizations and their stakeholders (Luoma-aho \& Paloviita, 2010).

But why is exploring citizens' expectations relevant for public sector organizations and their communication? While citizen satisfaction has long been an area of research, citizen expectations are newer on the agenda (Van Ryzin, 2004a), despite the importance they have for public organizations' development. There is consensus in the research literature that citizens' expectations about public sector performance shape their overall satisfaction with the public 
sector and its services (James, 2009a; Luoma-aho, Olkkonen, \& Lähteenmäki, 2013b; Poister \& Thomas, 2011a; Roch \& Poister, 2006; Van Ryzin, 2004b; Van Ryzin, 2006). In fact, the level of satisfaction shapes not only the attitudes of citizens but also their behavior (James \& John, 2007; Thijs \& Staes, 2008).

Citizens' expectations of the public sector influence whether they remain loyal, cease to engage with a service, or voice their dissatisfaction (Hirschman, 1970), and hence managing expectations is of strategic value. If citizen satisfaction can be improved by managing what has been referred to as "normative expectations" (Summers \& Granbois, 1977), it is less likely that citizens will vote against those in charge of public services or complain about services (Boyne, James, John, \& Petrovsky, 2009; Dowding \& John, 2008; James \& John, 2007). Research suggests that positive expectations are negatively related to complaints about public services and voting against incumbents because positive expectations relate to the performance citizens think they will experience if they use a service. Positive expectations are positively related to service use for the same reason, and citizens choose services that they have high positive expectations about in situations in which they can select from between available services (James, 2011, 14211422). Thus, the topic of citizens' expectations is one of great interest for public sector communication research and practice.

Part one of this chapter explores the notion of citizen expectations, providing definitions of different types of expectations. Since scholarly research has found an intrinsic connection between expectations and citizen satisfaction, this latter notion and its interplay with citizen expectations are examined. The disciplinary context, methods, frames, and models for citizen expectations research, as well as major research findings, are also set out. The second part of the chapter explores what a more elaborate understanding of citizen expectations can add to 
communication management, describing both the theoretical relevance of the topic to public sector communication as well as the communication performance dimension in relation to prerequisites, constraints, and effects on organizational culture, with a consideration of practical implications for public managers. Finally, the chapter deals with major challenges, critiques, unanswered questions, and future research in this area.

\section{DEFINING CITIZEN EXPECTATIONS}

According to Luoma-aho \& Olkkonen (2016, 303), "Expectations are mental models that affect the formation of relationships that individuals and stakeholders have with each other, organizations and brands." Expectations can refer to behaviors expected of the organization (Coye, 2004), and they act as reference points for future assessments (Creyer \& Ross, 1997) guiding citizens' perceptions of the organization or service (Luoma-aho, Olkkonen, \& Lähteenmäki, 2013a). Expectations can have diverse origins such as values, available information, previous experiences, or personal interests (Olkkonen \& Luoma-aho, 2015). As a result, they are a rich phenomenon.

\section{Types of citizen expectations}

Research in organizational communication and public relations has linked meeting expectations to the ability to shape stakeholders' attitudes, motivation, behavior, and satisfaction toward the organization (Eisenegger \& Imhof, 2008; Reichart, 2003; Thomlison, 2000), which explains why organizations perceive positive expectations as a valuable resource. Based on both planned and unplanned cues (Coye, 2004), expectations filter information about i) whether events are desirable or undesirable from the citizen's point of view and ii) how likely it is that the event will occur (James, 2009a; Olkkonen \& Luoma-aho, 2014a; Olkkonen \& Luoma-Aho, 
2015a; Poister \& Thomas, 2011a; Van Ryzin, 2006). Thus, there are normative and predictive elements in expectations.

The predictive element in expectations relates to likelihood, and it describes what will probably occur. Therefore, expectations as predictive constructions describe an estimation of what will happen (Summers \& Granbois, 1977). In the case of the public sector, predictive expectations can concern issues that are related to, for example, public decision making processes or the variety of services provided. The normative element of expectations relates to what is considered as desirable or valued (what should or ought to be) by the stakeholders who are forming the expectations (Miller, 1977; Summers \& Granbois, 1977). Normative expectations are more static than predictive expectations, and they can take different levels, relating to, for example, what is considered the least acceptable level (minimum expectations, Miller, 1977; or must expectations, Olkkonen \& Luoma-aho, 2014a). These are the minimum requirements for public sector organizations to fulfill; examples of such obligations include maintaining stability in society and providing certain basic services such as healthcare. Normative expectations can also take place at a level that is considered possible with current resources (Summers \& Granbois, 1977). For the public sector, these may relate to topics such as the electoral process or certain public sector services such as nuclear safety or education. Finally, normative expectations may relate to what is considered the ideal state of affairs (Miller, 1977) or to what the state of affairs could be (Olkkonen \& Luoma-aho, 2014a). These expectations take place on the highest level, representing wants and needs such as citizens' good experiences of public service providers.

When there is a gap between reality and expectations, the influence of the media on citizens' perceptions increases (Park \& Blenkinsopp, 2011). As seeking to renew positive 
emotions and avoiding repeats of negative ones are embedded in human behavior (Nesse, 1990), stakeholders may attempt to prevent future disappointments by intentionally adjusting their (predictive) expectations to a lower level (Van Dijk, Zeelenberg, \& Van der Pligt, 2003). In practice, intentionally lowered expectations can relate to problems with trust and transparency, such as when corruption is perceived to obstruct public processes (Canel \& Luoma-aho, 2017; Nigro \& Gonzales Cisaro, 2014; Park \& Blenkinsopp, 2011). In fact, transparency as a value is "likely to change the relation between citizens and authorities" as citizens expect more from public sector communication (Holzner \& Holtzner, 2006, 114).

\section{Citizen expectations and citizen satisfaction}

Citizen satisfaction can be understood as an intangible, multidimensional construct that includes citizen approval of public sector actions and the public sector's fulfillment of citizens' needs and its meeting of citizens' expectations (Cappelli, Guglielmetti, Mattia, Merli, \& Renzi, 2010; Nigro \& Gonzales Cisaro, 2014). It is a measure of the level of pleasure citizens feel and an emotional reaction to a specific transaction (Oludele, Emilie, \& Mandisa, 2012). In light of expectations, satisfaction depends on how well the actual experiences meet the level that was expected, as is explained by Oliver $(1980,461)$.

Satisfaction is generally examined on two levels:

a) the general level of satisfaction overall;

b) the more specific level of satisfaction in relation to individual services and products. Although these two levels often overlap, and although it may be difficult for individual citizens to distinguish them in practice, it is possible that on one level there is satisfaction while simultaneously on the other there is dissatisfaction. Such cases are often reported, for example, by citizens who are dissatisfied overall with the public sector or the political system at large but 
actually assess their personal experiences with certain public sector services as quite good (Thijs $\&$ Staes, 2008). Thus, citizen satisfaction is understood to be a "combination of general and subjective assessments of the experiences people have with public services, which include not only feelings or opinions about 'objective services' but also judgmental evaluations” (Im \& Lee, $2011,2)$. Satisfaction consists of "different constituent elements identified by the various aspects of the service" (Cappelli et al., 2010, 270).

The interplay of expectations and satisfaction is complex. In view of Oliver's $(1980,460)$ assertion that "satisfaction increases as the performance/expectation ratio increases," understanding citizen expectations is important for public sector organizations that hope to ensure that they have satisfied citizens. While not all citizens are even aware of their expectations before they are disappointed or gaps emerge (Sethi, 1979), research has shown a link between unmet expectations and citizens' level of satisfaction with public sector services (Font \& Navarro, 2013; James, 2009a). Satisfaction is understood to be "a function of an initial standard and some perceived discrepancy from the initial reference point" (Oliver, 1980, 460), with that "initial reference point" often understood to be expectations. In fact, US-based research suggests that citizens' expectations play a larger role in determining satisfaction at the federal level than they do at the local level, and this may be explained partly by the priming effect of citizens' intensive practical experiences (for example, filing taxes) on directing their expectations toward more realistic levels (Morgeson, 2012). Consequently, citizens' more realistic expectations are easily met.

Figure 1 shows the positive and negative extremes and the interrelated nature of expectations and satisfaction. Dissatisfaction or satisfaction arise from experiences that are evaluated based on unconscious and conscious expectations. Reality often falls somewhere in 
between, and in it citizens may hold simultaneous and overlapping expectations of both positive and negative kinds, and experiences blend together both forms.

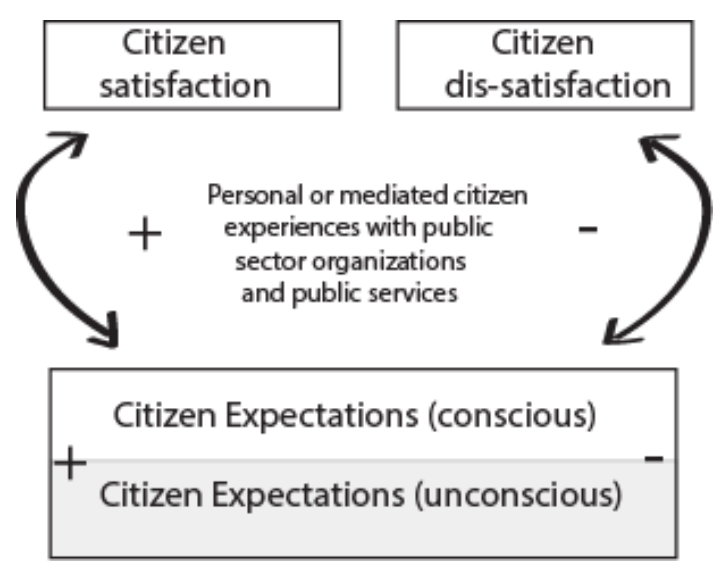

Figure 1. The link between expectations and satisfaction.

\section{The disciplinary context, methods, and models for citizen expectations research}

Citizen expectations are relevant in democracies, where the system-ideally, at leasthas been set up for the people by the people. Studies focused on citizen expectations and satisfaction draw on various disciplines, and research on them crosses the traditional boundaries of political science, marketing, interpersonal communication, public administration, corporate and organizational communication, public relations, and sociology. Outside the area of public sector communication, expectations, satisfaction, and their impact on relationships have been considered in interpersonal communication research (for example, Burgoon, 1993; Thomlison, 2000) as well as in customer management and customer satisfaction studies (e.g., Zeithaml, Berry, \& Parasuraman, 1993), where the focus has been on how customers evaluate and judge satisfaction. The public relations literature examines the issue of expectations through the prism 
of relationship building, since meeting expectations is essential for the continuation of relationships between organizations and stakeholders (Olkkonen \& Luoma-aho, 2014a).

Regarding the research methods that have been deployed to examine citizen expectations and satisfaction, more measures have been developed for the latter than for the former. Most often, satisfaction is measured through survey tools developed for specific cases and contexts, and the results obtained are not generalizable. On the global level, there are cross-national surveys covering satisfaction such as the European Social Survey. Works on citizen satisfaction have become more prominent in the past twenty years as the total quality management paradigm has gained ground. Satisfaction is usually viewed as a measure ranging from satisfied to dissatisfied. Typical approaches to measuring citizen satisfaction include surveys that may involve i) comparison and benchmarking; ii) analysis of key drivers, or iii) analysis of importance (Nigro \& Gonzales Cisaro, 2014). As with all measurements of human subjects, surveys on citizen satisfaction and expectations may or may not measure reality and are subject to priming, framing, and other biases (Van de Walle \& Van Ryzin, 2011).

The combination of expectations and satisfaction has been tested through the expectancy disconfirmation model (Van Ryzin, 2004a), which combines four measures: i) expectations about the overall quality of public services, ii) perception of overall quality, iii) confirmation or disconfirmation of prior expectations, and iv) overall citizen satisfaction (Morgeson, 2012).

The measures chosen depend on the context of citizen satisfaction. Most studies of service quality or public sector service satisfaction take the approach of measuring satisfaction, lack of satisfaction, and dissatisfaction with some form of public service (Park \& Blenkinsopp, 2011). Often satisfaction is measured in comparison with the quality criteria set for the public sector organization or service in question (Thijs \& Staes, 2008), but more tangible measures also 
exist and are used in cases such as measuring satisfaction with a specific locality or city (Zenker, Petersen, \& Aholt, 2013).

Individuals search for logical and causal explanations for events and the behavior of organizations and other individuals. Citizens aim to predict future events by comparing the likelihood that they will occur with their previous personal experiences. These experiences make for a form of internal frames, and these filter information and portray it in the context of a certain environment, helping citizens make sense of the events and the situation. Evaluations are made as to whether the behavior or event meets the broad general anticipation of societal and cultural norms and whether it matches the detailed case-related individual experiences and previous knowledge (Luoma-aho \& Olkkonen, 2016).

Trust is often a key variable when it comes to explaining or contributing to measures of citizen satisfaction (Park \& Blenkinsopp, 2011), and it is also central to citizen expectations. Trust is based on the positive expectations that one has concerning the intentions or behavior of another person (Rousseau, Sitkin, Burt, \& Camerer, 1998) and on the subjectively judged likelihood that this person will not act in a manner contrary to one's expectations (Nooteboom, Berger, \& Noorderhaven, 1997). Trust in government or public services (and, by association, expectations), is measured through citizens' subjective judgments that are based on their experience of how the government is meeting their needs (Park \& Blenkinsopp, 2011). The major method used is surveys such as the Edelman Trust Barometer, which goes beyond individual country case studies and provides data for comparative research. Trust and satisfaction are frequently found together; trust is seen to be generated when a relational partner meets expectations, with this in turn reinforcing future positive expectations and generating a feeling of satisfaction (Olkkonen \& Luoma-aho, 2014, 4). 
Another variable contributing to the measurement of citizen expectations and satisfaction is citizen assessment of governmental public policy performance. Formal systems of published performance assessment produced by auditors, inspectors, and other bodies generate data about outcomes, efficiency, and effectiveness that can affect people's expectations. James and Moseley (2014) tested the effects of information provided by local authorities regarding public services on citizens' expectations, satisfaction, and assessments, and their study highlights the importance of field experiments in understanding citizens.

A growing research area uses the expectancy disconfirmation model (EDM) (Oliver, 1980), which combines expectations with actual assessments and satisfaction (Morgeson, 2012; Van Ryzin, 2004a). The EDM combines pre- and postservice expectations with performancebased confirmation or disconfirmation of the expectations, resulting in satisfaction or dissatisfaction with the experience (Morgeson, 2012). Within the research field of public relations, expectations are connected to areas such as issues management, risk perception, and reputation (Olkkonen \& Luoma-aho, 2014b). As satisfaction is often related to a specific service, citizen satisfaction research has taken its lead from marketing approaches such as the total quality management model (Pollitt, Pollitt, Van Thiel, \& Homburg, 2007). However, researchers do not agree as to whether these business-oriented concepts and ideals are suited to the public sector (Wæraas \& Maor, 2015). In fact, as expectations and satisfaction are intangible constructs, they are always context dependent, and as intangibles, the challenges include "inseparability between production and consumption, perishability and heterogeneity" (Carvalho, Brito, \& Cabral, 2010).

\section{Research findings on citizen expectations}


A growing trend in citizen expectations research is to put the customer (Mickelsson, 2013) or citizen (Bourgon, 2009) at the center of the exchange or relationship, and as has been mentioned, a key issue here is the relation between expectations and satisfaction. Although there is a connection between the two, public service quality does not necessarily lead to satisfaction: there is a complex interplay between reality, perceptions, and expectations (Bouckaert, Kampen, Maddens, and Van de Walle 2001; Wan de Walle \& Bouckaert, 2003, 892; Carmeli \& Tishler, 2005). Research usually finds gaps between what managers think their performance is and what citizens (their stakeholders) think it actually is (Sanders \& Canel, 2015); gaps are even found between citizens' perceptions and perceptions of auditors and inspectors of services (James \& Moseley, 2014).

Extremely satisfied or dissatisfied citizens are more susceptible to the impact of expectations than those in the middle range of satisfaction or dissatisfaction are. The extremes, both positive and negative, seem to have a stronger association with positive expectations than mid-range performance does (James, 2011). In fact, it appears to be the case that the higher the expectation, the higher the possibility of dissatisfaction (James, 2009b). This dynamic highlights the need to maintain neutral levels of reputation in the public sector and means that excellence might not be the most appropriate goal (Luoma-aho, 2007).

Citizens' expectations often stem from their experiences at the local level of public services and the prior performance of local government (James, 2011). Where expectations are met, the predicted probability of dissatisfaction is very low compared to the predicted probability of satisfaction. In fact, "declining trust will create an environment of deflated expectations that in turn may prove detrimental to citizen satisfaction" (Morgeson, 2012, 15). 
Although researchers agree that met expectations reduce citizens' dissatisfaction, they do no not necessarily increase citizen satisfaction. There is a difference between meeting expectations and exceeding them, as it has been argued that exceeding the expected quality has a more direct positive effect on citizen satisfaction (Van Ryzin, 2006).

The role of public sector employees is yet another perspective that has been explored (Perry \& Porter, 1982). These street-level civil servants are believed to shape citizens' experiences and expectations more than organizations do, as public sector employees often make the practical policy decisions that affect individual citizens and their lives the most (Lipsky, 2010). Employee research has found support for both similarities and differences between private and public sector settings when it comes to employee motivation for work and service (Goulet \& Frank, 2002). The major difference appears to be that public sector employees, when compared to private sector employees, are less motivated by monetary rewards (Belle \& Cantarelli, 2015), highlighting their high morale and motivation to serve citizens. This insight forms a good foundation for building a relationship characterized by realistic and positive expectations, as perceptions as to whether authorities are ethical and trustworthy have been linked with citizen expectations toward the organizations that the authorities represent (Luoma-aho, 2005).

There are mixed findings in relation to the question of whether expectations about participation shape citizen satisfaction for better or worse. As for participatory mechanisms (for example, public hearings, citizen juries, and participatory budgeting), Font and Navarro (2013) note that direct experience of these processes led to a more negative evaluation of their performance relative to the higher expectations held by those who were unfamiliar with them. On the other hand, reports on citizen satisfaction tend to argue that citizens award better evaluations to and expect more from services that they have experienced personally (Thijs \& Staes, 2008). 


\section{CITIZEN EXPECTATIONS AND PUBLIC SECTOR COMMUNICATION}

\section{How do citizen expectations shape the relationship between citizens and public sector organizations?}

Citizen expectations and satisfaction are understood to be formed mostly in the context of relationships or, rather, pseudorelationships (Gutek, 2000), in which citizens can identify a service or an organization but not necessarily the corresponding individual public servant or provider (Carvalho et al., 2010). A pseudorelationship between citizens and public sector organizations consists of successive encounters and episodes during which citizens' experiences evolve (Gutek, 2000), with both satisfactory and unsatisfactory episodes often occurring (Carvalho et al., 2010). It is hence possible for citizens to be simultaneously satisfied and dissatisfied with public sector organizations and their services. Some have suggested citizen satisfaction will be higher when individual services are mentioned than it will be when public services in general are the focus (Thijs \& Staes, 2008), but recent research has noted the importance of question order and priming on reported satisfaction levels (Van de Walle \& Van Ryzin, 2011). The context within which expectations and satisfaction form can be understood to consist of three parties: the citizen, the public sector organization, and society with its diverse stakeholders (Carvalho et al., 2010). In practice, there are several other aspects that feed into the relationship, including the media, other citizens, situational factors, the societal setting, and the level of democracy, as well as priming and context (Nigro \& Gonzales Cisaro, 2014; Olkkonen \& Luoma-aho, 2015b; Thijs \& Staes, 2008; Van de Walle \& Van Ryzin, 2011). 
Communication is often listed as a source of dissatisfaction in relation to the public sector despite its central function in enabling democracy in public services (Luoma-aho \& Canel, 2016). Some have even suggested that citizen dissatisfaction results from unmanaged or false expectations. There are findings that suggest that information provision on specific public services' prior performance (such as number of citizens helped or complaints processed) influences citizens' expectations (James, 2011). The level at which citizens expect public sector organizations to communicate shapes their satisfaction and their assessment of, for example, the organization's reputation (Sanders \& Canel, 2015).

Early research on expectations and satisfaction lists communication as one of the three central factors in shaping individual experiences. Borrowing from adaptation phenomena, Oliver $(1980,461)$ argues that expectations are influenced by the product or service itself based on prior experience, connotations, symbols, and "the context including the content of communications from sales people and social referents," as well as on other individual characteristics such as the individual's susceptibility to persuasion.

There are often discrepancies between what public sector organizations and local governments think about their reputation on the one hand and what citizens think on the other, but the cause-and-effect relations are complex, as experiences are intangible and volatile. However, once citizens' have established views on the public sector-for example, opinions on the reputation of specific sectors - these positions seem to remain quite stable over time (Luomaaho, 2008).

Citizen expectations and satisfaction are crucial elements for public sector communication, as they either facilitate or prohibit public sector communication. In fact, communication plays a dual role in priming citizen expectations to a realistic level and ensuring satisfaction through 
sufficient disclosure and dialogue (Canel \& Luoma-aho, 2017). Priming is important, as the content of information and the emotions associated with it shape citizen perceptions: satisfaction increases if citizens receive positive information about public services (James, 2011).

If public sector organizations' communication does not reflect citizen expectations, satisfaction decreases (Poister \& Thomas, 2011b). Expectations and biases establish the way in which citizens "hear" public sector organizations and their communication.

\section{Communicating in the public sector by taking citizens' expectations into account}

All communication requires interaction, and as long as public sector organizations control the communication process and merely issue their own messages instead of listening, citizen satisfaction may remain difficult to achieve (Macnamara, 2015). Existing human biases such as negativity bias (Dolan et al., 2010) easily turn satisfaction levels negative, and this poses several challenges for public sector communicators (Olsen, 2015). Moreover, the news criteria for legacy media still hold negativity as central, and as the new media environment and social media context have made it easier for citizens to share their experience, public sector organizations face the challenge of keeping up with citizen expectations.

But measures of citizen satisfaction and citizen expectations, as is the case with most measures, may threaten to become aims in themselves and drive public sector organizations to base their behavior solely on them. Ideal citizen satisfaction results from truly meeting citizen needs, but if these needs are established through communication, a new challenge emerges: How do we truly know whether expectations are being shaped and set by actual needs or by public sector communication?

\section{Practical implications for public sector managers}


As the standards of what citizens are satisfied with or expect can change over time (Oliver, 1980) and vary between different stakeholder groups (Gardberg \& Fombrun, 2006), citizens' expectations should be continually monitored for changes.

The study of citizen expectations contributes to a specific communication culture and can inspire four specific practices. First, governments can gain strategic advantages by using expectation management to strengthen communication management. An organization with good expectation management has a better chance of matching its behavior with its communication, thus avoiding the creation of unintended or misleading expectations (Olkkonen \& Luoma-aho, 2014b). Research could provide governments with route maps for authorities to communicate to citizens what can be expected from specific public policies at certain times and in particular contexts.

Second, monitoring different types of citizen expectations about public policies might help identify and calibrate gaps between what citizens expect and what they actually experience. Previous studies have suggested establishing a "fit or fix" matrix to help public managers distinguish what to do with mismatched expectations in practice. "Fix" refers to cases where the organization needs to calibrate its stakeholders' expectations through improved communication to better match its actions, whereas "fit" refers to the organization changing itself to correspond more effectively to existing expectations (see, Luoma-aho et al., 2013). Such a matrix would also help organizations respond to societal pressures and to the public's concerns about organizations. One task in expectation management is to aid publics in expressing their expectations, since a known expectation can be responded to (Olkkonen \& Luoma-aho, 2014a).

Third, expectation research could also provide guidelines for careful interpretation of citizens' assessment of government performance. As research has shown, low average 
satisfaction scores might be due not to low performance but to (mistakenly) high expectations. Similarly, high average satisfaction might be due not to high performance but to low expectations. Expectations need to be taken into account alongside more conventionally understood factors when using satisfaction surveys as a performance measure.

Finally, expectations research might help to identify the ideal level of what citizens should be expecting from public services. The worldwide economic crisis of the past decade has made it more difficult for states' public sectors to invest the resources needed to maintain an excellent reputation, and specific research is required about what attributes public institutions should aim to have (such as efficiency, efficacy, representativeness, impartiality, equity, trustworthiness, reliability, transparency, and accountability). Research could provide governments with guidelines about how to build realistic and adequate citizen expectations about policy areas and public policy outcomes: the more realistic the expectations, the more likely it is that citizen satisfaction will emerge. In the current communication environment, public or private organizations are likely to find it hard to control expectations, but they may benefit from expectation management that aims to decipher and understand their stakeholders' expectations and the ways in which they are formed (Olkkonen \& Luoma-aho, 2014a; Luoma-aho \& Olkkonen, 2016).

In sum, expectation management implies monitoring publics in order to detect gaps between expectations and performance and assessing the reasons why they emerged, which may include, for example, overpromising or underdelivering. Ultimately, expectation management should make it possible to develop strategic responses that help in maintaining trust and legitimacy (Olkkonen \& Luoma-aho 2014b). 


\section{CRITIQUES, CHALLENGES, UNANSWERED QUESTIONS, AND FUTURE RESEARCH LINES}

Expectations and satisfaction are elements that will form with or without public sector organizations' communication. As such, expectations related to and satisfaction felt about public sector services can be manipulated with priming and unethical expectation management efforts. Expectation management also raises ethical challenges related to manipulation in the worst sense of the word: if citizen expectations are artificially kept at a low level, it is easier to exceed them and temporarily raise satisfaction (Thijs \& Staes, 2008). One central challenge remains citizens' experiences and their preexisting information about a topic (Olsen, 2015): citizen surveys are best administered to citizens who have experience of using the service (Luoma-aho, 2007). Some have argued that satisfaction is too related to marketing to suit the public sector (Wæraas \& Byrkjeflot, 2012). As most satisfaction surveys consist of certain standard statements, the order of items and the framing of words also represent challenges (Van de Walle \& Van Ryzin, 2011).

It currently seems that the most solid consensus concerning citizen expectations has to do with their complexity and whether there are direct causal relationships between public organizations' achievements, public policies' results, communication performance, and citizens' satisfaction and trust. The major disagreements are based on frequent mixed findings about what exactly increases or decreases expectations and, in turn, citizen satisfaction and trust. Scholars also still disagree about exactly how citizen satisfaction can best be measured (Van de Walle \& Van Ryzin, 2011) as well as about what creates expectations (James, 2011).

From a theoretical perspective, there are many areas to explore. For example, the gap model of service quality (Zeithaml, Berry, \& Parasuraman, 1993) has not attracted the interest of public sector communication scholars, though the model has been popular in customer 
satisfaction research as it measures satisfaction in terms of the "zone of tolerance" between expectations and perceived service. From the interpersonal communication literature, expectancy violation theory may offer fruitful avenues, as it explains the process of how expectations and their fulfillment are assessed (Burgoon, 1993).

Finally, as intangible assets, both expectations and satisfaction remain a mystery to some degree as they are individually formed and subject to change. In some cases, even an organization's best efforts may fail to meet some citizen expectations and achieve full citizen satisfaction. Future research could look into identifying the ideal level of expectations and better utilize existing citizen feedback on end-user experiences. And connections between trust and expectations are yet to be discovered, as is the role of expectations in legitimacy building.

\section{References}

Belle, N., \& Cantarelli, P. (2015). Monetary incentives, motivation, and job effort in the public sector: An experimental study with italian government executives. Review of Public Personnel Administration, 35(2), 99-123. doi:10.1177/0734371X13520460

Bourgon, J. (2009). New directions in public administration: Serving beyond the predictable. Public Policy and Administration, 24(3), 309-330. doi:10.1177/0952076709103813

Boyne, G. A., James, O., John, P., \& Petrovsky, N. (2009). Democracy and government performance: Holding incumbents accountable in English local governments. The Journal of Politics, 71(04), 1273-1284. doi:10.1017/S0022381609990089 
Canel, M., \& Luoma-aho, V. (2018). Public Sector Communication. Closing Gaps between Public Sector Organizations and Citizens. Wiley-Blackwell.

Cappelli, L., Guglielmetti, R., Mattia, G., Merli, R., \& Renzi, M. (2010). Statistical techniques for continuous improvement: A citizen's satisfaction survey. The TQM Journal, 22(3), 267284. doi:10.1108/17542731011035514

Carvalho, C., Brito, C., \& Cabral, J. (2010). Towards a conceptual model for assessing the quality of public services. International Review on Public and Nonprofit Marketing, 7(1), 69-86.

Castelo, N., Hardy, E., House, J., Mazar, N., Tsai, C., \& Zhao, M. (2015). Moving citizens online: Salience and framing as motivators for behavioral change. Journal of Behavioral Science and Policy, 1(2), 57-68.

Coye, R. W. (2004). Managing customer expectations in the service encounter. International Journal of Service Industry Management, 15(1), 54-71. doi:10.1108/09564230410523330

Creyer, E., \& Ross, W. T. (1997). The influence of firm behavior on purchase intention: do consumers really care about business ethics? Journal of Consumer Marketing, 14(6), 421432.

Dolan, P., Hallsworth, M., Halpern, D., King, D., \& Vlaev, I. (2010). MINDSPACE: Influencing behaviour through public policy. United Kingdom: Institute for Government, Cabinet Office, 2010.

Dowding, K., \& John, P. (2008). The three exit, three voice and loyalty framework: A test with survey data on local services. Political Studies, 56(2), 288-311. doi:10.1111/j.14679248.2007.00688.x 
Durose, C., Justice, J., \& Skelcher, C. (2015). Governing at an arm's length: Eroding or enhancing democracy? Policy \& Politics, 43(1), 137-153.

Font, J., \& Navarro, C. (2013). Personal experience and the evaluation of participatory instruments in Spanish cities. Public Administration, 91(3), 616-631. doi:10.1111/j.14679299.2012.02106.x

Fredriksson, M., Schillemans, T., \& Pallas, J. (2015). Determinants of organizational mediatization: An analysis of the adaptation of Swedish government agencies to news media. Public Administration, 93(4), 1049-1067. doi:10.1111/padm.12184

Gardberg, N. A., \& Fombrun, C. J. (2006). Corporate citizenship: Creating intangible assets across institutional environments. Academy of Management Review, 31(2), 329-346.

Goulet, L. R., \& Frank, M. L. (2002). Organizational commitment across three sectors: Public, non-profit, and for-profit. Public Personnel Management, 31(2), 201-210. doi:10.1177/009102600203100206

Gutek, B. (2000). Service relationships, pseudo-relationships, and encounters. In T. Swartz, \& D. Iacobucci (Eds.), Handbook of services marketing \& management (pp. 371-380) Sage Publications.

Hirschman, A. O. (1970). Exit, Voice and Loyalty: Responses to decline in firms, organizations, and states (Vol. 25). Harvard University Press.

Holzner, B., \& Holtzner, L. (2006). Transparency in Global Change: The Vanguard of the Open Society. Pittsburgh, PA: University of Pittsburgh Press. 
Im, T., \& Lee, S. J. (2011). Does management performance impact citizen satisfaction? The American Review of Public Administration, 42(4), 419-436, doi: $10.1177 / 0275074011408589$

James, O., \& Moseley, A. (2014). Does performance information about public services affect citizens' perceptions, satisfaction and voice behaviour? Field experiments with absolute and relative performance information. Public Administration, 92(2), 493-511. doi:10.1111/padm.12066

James, O. (2009a). Evaluating the expectations disconfirmation and expectations anchoring approaches to citizen satisfaction with local public services. Journal of Public Administration Research and Theory, 19(1), 107-123. doi:10.1093/jopart/mum034

James, O. (2009b). Evaluating the expectations disconfirmation and expectations anchoring approaches to citizen satisfaction with local public services. Journal of Public Administration Research and Theory, 19(1), 107-123. doi:10.1093/jopart/mum034

James, O. (2011). Managing citizens' expectations of public service performance: Evidence from observation and experimentation in local government. Public Administration, 89(4), 14191435. doi:10.1111/j.1467-9299.2011.01962.x

James, O., \& John, P. (2007). Public management at the ballot box: Performance information and electoral support for incumbent English local governments. Journal of Public Administration Research and Theory, 17(4), 567-580. doi:10.1093/jopart/mul020

Lipsky, M. (2010). Street-level Bureaucracy: Dilemmas of the Individual in Public Services. New York, NY: Russell Sage Foundation. 
Luoma-Aho, V., Olkkonen, L., \& Lähteenmäki, M. (2013a). Expectation management for public sector organizations. Public Relations Review, 39(3), 248-250.

Luoma-aho, V. (2007). Neutral reputation and public sector organizations. Corporate Reputation Review, 10(2), 124-143.

Luoma-aho, V., \& Canel, M. J. (2016). Public sector reputation. In C. Carroll (Ed.), Sage encyclopedia of corporate reputation. Sage.

Luoma-aho, V., \& Olkkonen, L. (2016). Expectation management. In C. Carroll (Ed.), The SAGE encyclopedia of corporate reputation. Sage.

Luoma-Aho, V. (2008). Sector reputation and public organizations. International Journal of Public Sector Management, 21(5), 446-467.

Luoma-aho, V., Olkkonen, L., \& Lähteenmäki, M. (2013b). Expectation management for public sector organizations. Public Relations Review, 39(3), 248-250.

Luoma-aho, V. (2005). Faith-holders as social capital of Finnish public organizations. Jyväskylä: University of Jyväskylä.

Macnamara, J. (2015). Creating an Architecture of listening' in Organizations. (Research Report No. May). Sydney, NSW: University of Technology Sydney.

Mickelsson, K. (2013). Customer activity in service. Journal of Service Management, 24(5), 534552. doi:10.1108/JOSM-04-2013-0095

Morgeson, F. V. (2012). Expectations, disconfirmation, and citizen satisfaction with the US federal government: Testing and expanding the model. Journal of Public Administration Research and Theory, doi:10.1093/jopart/mus012 
Nigro, H. O., \& Gonzales Cisaro, S. E. (2014). Prediction of citizen satisfaction with local government based on perceptions of physical disorder. Journal of Place Management and Development, 7(2), 153-175. doi:10.1108/JPMD-09-2013-0021

Nooteboom, B., Berger, H., \& Noorderhaven, N. (1997). Effects of trust and governance on relational risk. Academy of Management Journal, 40(2), 308-338.

Oliver, R. (1980). A cognitive model of the antecedents and consequences of satisfaction decisions. Journal of Marketing Research, 17, 460-469.

Olkkonen, L., \& Luoma-aho, V. (2014a). Public relations as expectation management? Journal of Communication Management, 18(3), 222-239.

Olkkonen, L., \& Luoma-Aho, V. L. (2015a). Broadening the concept of expectations in public relations. Journal of Public Relations Research, 27(1), 81-99.

Olsen, A. L. (2015). Citizen (dis)satisfaction: An experimental equivalence framing study. Public Administration Review, 75(3), 469-478. doi:10.1111/puar.12337

Oludele, A. A., Emilie, C. K., \& Mandisa, P. M. (2012). An analysis of citizen satisfaction with public service delivery in the Sedibeng district municipality of South Africa. International Journal of Social Economics, 39(3), 182-199. doi:10.1108/03068291211199350

Park, H., \& Blenkinsopp, J. (2011). The roles of transparency and trust in the relationship between corruption and citizen satisfaction. International Review of Administrative Sciences, 77(2), 254-274. doi:10.1177/0020852311399230

Perry, J. L., \& Porter, L. W. (1982). Factors affecting the context for motivation in public organizations. Academy of Management Review, 7(1), 89-98. doi:10.5465/AMR.1982.4285475 
Poister, T. H., \& Thomas, J. C. (2011a). The effect of expectations and expectancy confirmation/disconfirmation on motorists' satisfaction with state highways. Journal of Public Administration Research and Theory, 21(4), 601-617. doi:10.1093/jopart/mur004

Poister, T. H., \& Thomas, J. C. (2011b). The effect of expectations and expectancy confirmation/disconfirmation on motorists' satisfaction with state highways. Journal of Public Administration Research and Theory, 21(4), 601-617, doi:10.1093/jopart/mur004

Pollitt, C., Pollitt, C., Van Thiel, S., \& Homburg, V. (2007). New Public Management in Europe: Adaptation and Alternatives. Basingstoke, UK: Palgrave Macmillan.

Roch, C. H., \& Poister, T. H. (2006). Citizens, accountability, and service satisfaction: The influence of expectations. Urban Affairs Review, 41(3), 292-308. doi: $10.1177 / 1078087405281124$

Rousseau, D. M., Sitkin, S. B., Burt, R. S., \& Camerer, C. (1998). Not so different after all: A cross-discipline view of trust. Academy of Management Review, 23(3), 393-404.

Sanders, K., \& Canel, M. J. (2015). Mind the gap: Local government communication strategies and Spanish citizens' perceptions of their cities. Public Relations Review, 41(5), 777-784. doi:http://dx.doi.org/10.1016/j.pubrev.2015.06.014

Summers, J. O., \& Granbois, D. H. (1977). Predictive and normative expectations in consumer dissatisfaction and complaining behavior. Advances in Consumer Research, 4(1), 155-158.

Sethi, S. P. (1979). A conceptual framework for environmental analysis of social issues and evaluation of business response patterns. Academy of Management Review, 4(1), 63-74. 
Thijs, N., \& Staes, P. (2008). European primer on customer satisfaction management. The Netherlands: European Institute for Public Administration \& European Public Administration Network.

Van de Walle, S., \& Van Ryzin, G. (2011). The order of questions in a survey on citizen satisfaction with public services: Lessons from a split-ballot experiment. Public Administration, 89(4), 1436-1450. doi:10.1111/j.1467-9299.2011.01922.x

Van Dijck, J., \& Poell, T. (2013). Understanding social media logic. Media and Communication, $1(1), 2-14$.

Van Ryzin, G. G. (2004a). Expectations, performance, and citizen satisfaction with urban services. Journal of Policy Analysis and Management, 23(3), 433-448. doi:10.1002/pam.20020

Van Ryzin, G. G. (2004b). Expectations, performance, and citizen satisfaction with urban services. Journal of Policy Analysis and Management, 23(3), 433-448. doi:10.1002/pam.20020

Van Ryzin, G. G. (2006). Testing the expectancy disconfirmation model of citizen satisfaction with local government. Journal of Public Administration Research and Theory, 16(4), 599611. doi:10.1093/jopart/mui058

Wæraas, A., \& Maor, M. (Eds.). (2015). Organizational Reputation in the Public Sector. London: Routledge.

Wæraas, A., \& Byrkjeflot, H. (2012). Public sector organizations and reputation management: Five problems. International Public Management Journal, 15(2), 186-206. 
Zenker, S., Petersen, S., \& Aholt, A. (2013). The citizen satisfaction index (CSI): Evidence for a four basic factor model in a german sample. Cities, 31, 156-164.

doi:http://dx.doi.org/10.1016/j.cities.2012.02.006 